\title{
Osteomiyelitte VAC tedavisi
}

\section{Vacuum assisted therapy in the treatment of osteomyelitis}

\author{
Erhan Okay ${ }^{1}$, Korhan Özkan² \\ 1İstanbul Medeniyet Üniversitesi, Göztepe Eğitim ve Araştırma Hastanesi, Ortopedi ve Travmatoloji Kliniği, İstanbul \\ ${ }^{2}$ İstanbul Medeniyet Üniversitesi Tıp Fakültesi, Göztepe Eğitim ve Araştırma Hastanesi, Ortopedi ve Travmatoloji Anabilim Dalı, İstanbul
}

\begin{abstract}
Negatif basınçlı vakum tedavisi, son 20 yılda ortopedi ve travmatoloji alanında yaygın olarak kullanılmaktadır. İmplant cerrahisi sonrası gelişen açık yaralarda, primer onarımın mümkün olmadığı yaygın doku hasarlarına bağlı meydana gelen yumuşak doku defektlerinde, gecikmiş primer kapama öncesinde ve yumuşak doku flep veya greftleme cerrahisi öncesi granülasyon dokusu oluşumuna yardımcı bir teknik olarak, ayrıca yanık olgularında, diyabetik ayak ve diğer dolaşım bozukluklarına bağı gelişen ülserlerin tedavisinde sıkça tercih edilmektedir. Bu nedenlere bağlı olarak gelişen mevcut yumuşak doku örtüm sorunları, hastalarda artmış morbiditeye ve hastane maliyetlerinde artışa neden olmaktadır. Bu yazının amacı, negatif basınçlı vakum tedavisinin osteomiyelit ve buna bağlı gelişen yumuşak doku defektlerinde kullanım endikasyonlarını özetlemek ve konuyla ilgili güncel literatüre genel bir bakış sağlamaktır.
\end{abstract}

Anahtar sözcülkler: osteomiyelit; VAC tedavisi; debridman
B irçok koruyucu önlemlere rağmen artroplasti ve osteosentez sonrası enfeksiyon görülme sıklığı \%1-12'dir. ${ }^{[1]}$ Ortopedik enfeksiyonlar, morbiditede artış ve ekonomik maliyet yaratmaktadır.[2,3] Bunun dişında uzun kemiklerde rezeksiyonu takiben yapılan endoprostetik rekonstrüksiyon sonrasında enfeksiyon riski daha da fazladır. ${ }^{[4]}$ Bu tip enfeksiyonlara polimikrobiyal patojenler de sıklıkla eşlik etmektedir. ${ }^{[5]}$ Vakum yardımlı yara tedavisi, 1990'lı yılların başında $A B D$ ve Almanya'da ortaya çıkan bir tedavi yöntemidir. ${ }^{[6,7]}$ ilk defa yara iyileşmesini hızlandırmak amacıyla uygulanmıştır. Ancak ortopedi ve travmatoloji alanındaki enfeksiyon tedavisinde de artan sıklıkla kullanılmaya başlanmıştır. Ortopedik enfeksiyonların tedavisinde en büyük sorun, bakterilerin oluşturduğu biyofilm tabakasıdır. Bu durum, ortopedik implantlara ve protezlere bağlı gelişen enfeksiyonlarda, osteomiyelitlerde tedavi başarısının oldukça düşük olmasına yol açmaktadır. Bu sorunu azaltabilecek çalışmalar ve
Over the last 20 years, negative pressure vacuum assisted therapy has been widely used. This modality is often utilized in wound defects after implant surgery, soft tissue defects with impossibility of primary closure due to severe soft tissue injuries, as an adjunct for soft tissue granulation before delayed primary closure and flap reconstruction also in burn cases, ulcers due to diabetic foot, sore pressures and vascular compromise. Problems related to soft tissue coverage due to these reasons cause increased morbidity and hospital costs. The aim of this article is to summarize indications for negative pressure vacuum assisted therapy in osteomyelitis and its related soft tissue defects and to provide an overview of current literature.

Key words: osteomyelitis; VAC therapy; debridement arayışlar tüm dünyada devam etmektedir. Bu derleme makale, travma veya ortopedik implantların kullanımı sonrası gelişen osteomiyelit olgularında VAC (vacuum assisted closure) ile tedavi yöntemi hakkında güncel literatüre genel bir bakış sağlamayı amaçlamaktadır.

\section{ETKI MEKANIZMASI}

VAC tedavisinde amaç, aralıklı veya devamlı olarak yara bölgesine kontrollü negatif basıncın sağlanmasını, basıncın yara bölgesine eşit olarak dağılmasını ve sıvının sürekli olarak yara bölgesinden emilimini sağlamaktır. Tedavi sayesinde hücreler arası boşluktaki ödem azalır, doku kanlanması ve granülasyon dokusu formasyonu artar ve böylece yara kapanması hızlanır. ${ }^{\left[{ }^{[8]}\right.}$ Granülasyon dokusu oluşumu, kapiller kan akımının hızlanması, anjiyogenez (damarlanmada artış) ve endotel hücre çoğalmasının artması aracılığıyla meydana gelmektedir. Yine VAC tedavisiyle elde edilen

- İletişim adresi: Prof. Dr. Korhan Özkan, İstanbul Medeniyet Üniversitesi Tıp Fakültesi, Göztepe Eğitim ve Araştırma Hastanesi, Ortopedi ve Travmatoloji Anabilim Dalı. Eğitim Mah. Dr. Erkin Cad. Kadıköy, 34722 İstanbul Tel: 0532 - 2242448 e-posta: korhanozkan76@gmail.com

- Geliș tarihi: 11 Haziran 2020 Kabul tarihi: 26 Haziran 2020 
mekanik uyarı, hücrelerde IL-8 ve vasküler endotelial büyüme faktörleri aracilığıyla biyolojik etkiye dönüşmektedir. Böylece uygulanan bölgede neovaskülarizasyon (yeni damar oluşumu) artar.

\section{ORTOPEDI VE TRAVMATOLOJIDE KULLANIMI}

Vakum yardımlı kapama ile enfeksiyon tedavisine ait ilk yayınlarda spinal cerrahi sonrası derin fasya altında yerleşim gösteren enfeksiyonlar ile kapalı ayakbileği kırıklarının cerrahisi sonrası gelişen enfeksiyonların tedavisi anlatılmaktadır. ${ }^{[9-16]}$ Buna karşılık birkaç farklı yayında standart negatif basınç tedavisinin yarada artmış bakteriyal yüke sebebiyet verebileceği bildirilmiştir. [17-19]

Patmo ve ark. tarafından yapılan güncel bir sistematik derlemede, VAC tedavisi süresince yaradaki bakteriyal yük ve bakteri tipi değişimi açısından net sonuca varılamayacağı, VAC tedavisinin herhangi bir yarada enfeksiyona yol açmayacağı veya enfeksiyonu daha da kötüleştirmeyeceği sorusuna net bir cevap verilemeyeceği belirtilmiştir. ${ }^{[20]}$

Bu durum, instilasyonlu (yıkamalı) ve gümüşlü VAC tedavisi gibi bazı yeniliklerin önünü açmıştır.

İnstilasyonlu (yıkamalı) VAC tedavisi ile ilgili ilk ticari cihaz, 2003 yılında piyasaya girmiştir. Bu cihazın kanlanmayı, kollajen üretimini, granülasyon dokusu oluşumunu ve yara kontraksiyonunu artırdığı, bölgesel doku ödemini azalttığı ve buna bağlı bakteriyel biyofilm tabakası miktarını önemli ölçüde azalttı̆̆ı gösterilmiştir. ${ }^{[21,22]}$ Güncel olarak instilasyonlu (yıkamalı) negatif basınçlı yara tedavisi, kronik ve enfekte yaralar, osteomiyelit ve cerrahi implant enfeksiyonların tedavisinde kullanılmaya başlanmıştır. ${ }^{[23]}$ Erken ve geç dönem kalça eklemi enfeksiyonlarında etkinliği gösterilmiştir. ${ }^{[24]}$ Enfekte ortopedik implantlara bağlı gelişen kronik dönem enfeksiyonlarda ilk tecrübeler olumlu yöndedir. ${ }^{[25]}$

Timmers ve ark., travma sonrası (posttravmatik) osteomiyelit nedeniyle tedavi edilen 33 olguda polihekzanid solüsyon ile VAC tedavisi uygulamıştır. Sadece debridman uygulanan kontrol grubuyla karşılaştırıldığında, VAC tedavisi uygulanan grup, enfeksiyonun ortadan kaldırılması ve nüks etmesinin önlenmesinde istatiksel olarak daha önemli bulunmuştur. Yazarlar, polihekzanid solüsyon ile VAC tedavisinin, tekrarlayan debridman ve intravenöz antibiyotik tedavisini takiben oral antibiyotik tedavisinin verildiği standart postravmatik osteomiyelit tedavisinden farklı bir yaklaşım olduğunu belirtmişlerdir. Illeriki süreçte, bu tedavinin lavaj, nekrotik kemiğin uzaklaştırılması, sistematik ya da lokal antibiyotik tedavisi (gentamisin antibiyotik emdirilmiş boncuk) ile dirençli fistüllerde ıslak-ıslak pansuman uygulamasının yerini alabileceğini söylemişlerdir. ${ }^{[13]}$
Goss ve ark., 13 hastanın 16 alt ekstremite yarasında cerrahi debridman sonrasında yıkamalı negatif basınçlı VAC tedavisini uygulamışlar. Negatif basınçIı yıkamalı VAC uygulamasının Staphylococcus aureus, Corynebacterium ve Pseudomonas aeruginosa gibi üç etkenden oluşan bakteriyel biyolojik yükü (biologic burden) azaltmada başarılı olduğunu gözlemlemiştir.[${ }^{[23]}$ Söylemez ve ark., geç dönem dirençli periprostetik kalça enfeksiyonu nedeniyle radikal yara debridmanı ve sonrasında aralıklı negatif basınçlı yıkama uyguladıkları iki olgu rapor etmiştir. Bir ve üç yıllık takiplerde rekürrens görülmediğini belirtmiştir. ${ }^{[26]}$

Norris ve ark., implant çevresi enfeksiyon (üç hastada geç dönem, 13 hastada erken enfeksiyon, 10 travma ve altı elektif, beş spinal, beş üst ve altı alt ekstremite cerrahisi sonrası gelişen enfeksiyon) gelişen 16 hastada yıkamalı VAC tedavisi uygulaması ile implantlar çıkarılmadan enfeksiyonu tedavi etmiştir. ${ }^{[14]}$ Miyamura ve ark., kronik tibial osteomiyelit tanısı olan (CiernyMader tip 3) 64 yaş erkek hastada medüller kaviter bölgeye VAC tedavisi uyguladıkları bir olgu takdim etmiştir. Gastroknemius kas flebi uygulaması öncesinde VAC tedavisinin yara kapama sürecini ve enfeksiyon tedavisini basit hale getirdiğini belirtmişlerdir. ${ }^{[27]}$ Travma sonrası osteomiyelitin cerrahi tedavisi zor olabilmekte ve sonrasında nüks riski yüksek olmaktadır. Cerrahi debridman sonrası vakum yardımlı kapama yöntemleri yara iyileşmesini ve bölgesel kan akımını artırmaktadır. Antiseptik solüsyonlarla birlikte VAC uygulandığında, tedavi süresi, tekrarlayan operasyon süresi, yatış süresi ve enfeksiyonun rekürrens riski azalabilmektedir. ${ }^{[28]}$ Yıkama solüsyonları arasında, izotonik solüsyonlar, sodyum hipoklorit bazlı solüsyonlar (Dakin solüsyonu), biguanidinler, gümüş nitrat, hidrojen peroksit, povidon-iyodin ve özellikle polihekzametilen biguanid + betain kombinasyonu yer almaktadır. Betain biyofilm tabakasına penetre olarak polihekzametilenin biyofilm tabakası içinde daha aktif olarak antiseptik etki göstermesine yardımcı olmaktadır. ${ }^{[21,29]}$

Tan ve ark., Cierny-Mader tip 2, 3 ve 4 tanısı olan 68 hastaya VAC tedavisi (35 hasta) ve geleneksel yara bakımı (33 hasta) uygulamışlar. VAC tedavisi alan hasta grubunda osteomiyelit rekürrensinde azalma (7'ye karşı 1 yara, $\mathrm{p}<0,05)$, otodermoplasti ya da flep cerrahisi gereksiniminde azalma (26'ya karşı 17 yara, $\mathrm{p}<0,05)$, kültür negatifliği oranında artma (15'e karşı 29 yara, $\mathrm{p}<0,05)$ gözlemlemişlerdir. VAC tedavisinin cerrahi debridmanın yerini almayacağını, en önemli girişimin ölü kemik ve yumuşak dokunun debridmanı olduğunu vurgulamışlardır. Ancak VAC tedavisinin gerek kanlanmayı artırması gerekse biyofilm tabakası üzerine olan negatif etkileri nedeniyle tedavinin başarısını artıran bir yöntem olduğunu belirtmişlerdir. ${ }^{[15]}$ 


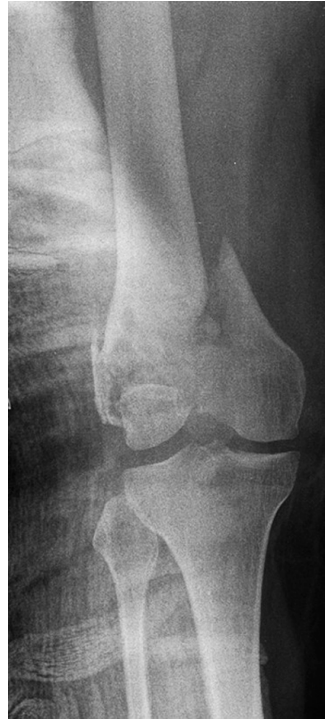

Şekil 1. Kırk yaşında bayan hasta; anevrizmal kemik kistine bağlı patolojik kırık gelişen hastanın grafisi (Olgu 1)

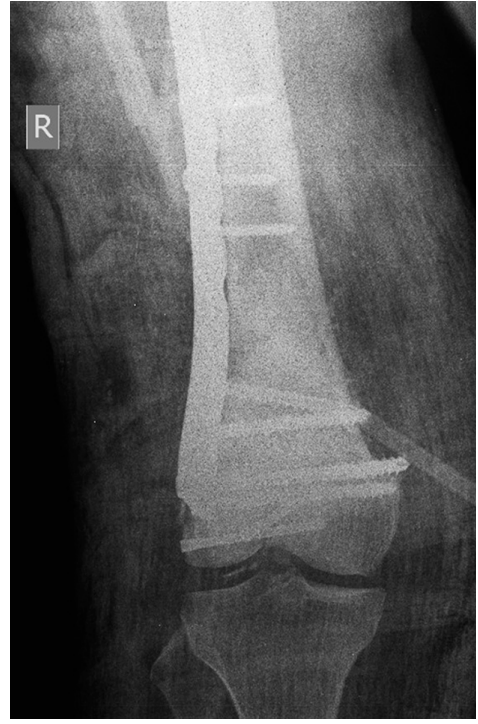

Şekil 2. Ameliyat sonrası grafi (Olgu 1).

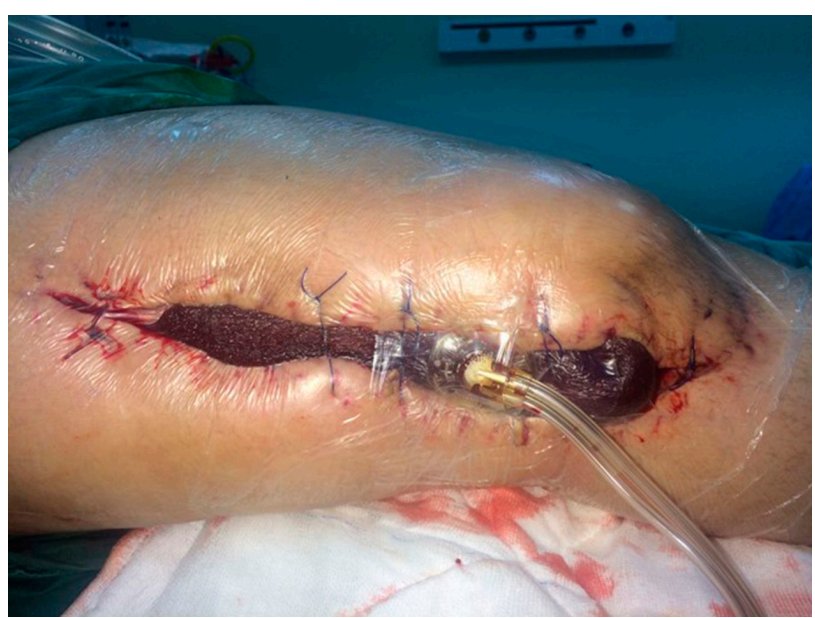

Şekil 3. Hastanın CRP düzeyleri normalleşince ve kültür negatifleşince VAC tedavisi sonlandırılıyor (Olgu 1).

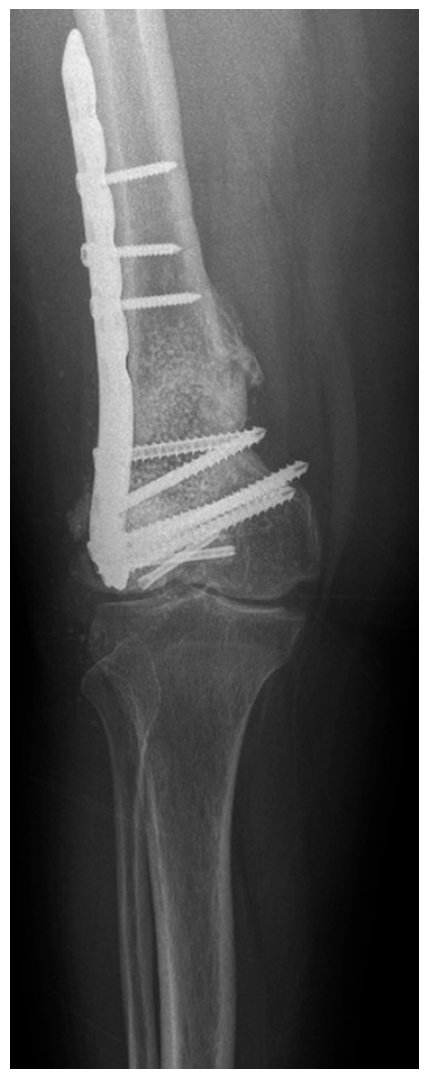

Şekil 4. Ameliyat sonrası 1. yıl takip grafisi; enfeksiyon bulguları yok ve tam kaynama görülmektedir (Olgu 1).

\section{Olgu 1}

Kırk yaşında bayan hasta, anevrizmal kemik kistine bağlı patolojik kırık oluşumu ile tarafımıza başvurdu (Şekil 1). Ameliyatta küretaj ve grefonaj sonrası plak vida ile tespit uygulandı. Ameliyat sonrası 3 . haftada dizde şişlik ve insizyon hattından akıntı başladı (Şekil 2). Alınan kültürlerde enterobakter ve Pseudomonas aeruginosa ürediği görüldü. Hastamıza dörder gün arayla üç seans yıkamalı VAC tedavisi uygulandı. Yıkama solüsyonu olarak Prontosan (B Braun) kullanıldı. Hastanın CRP düzeyleri normalleşince ve kültür negatifleşince VAC tedavisi sonlandırıldı (Şekil 3). Ameliyat sonrası 1. yıl takiplerinde enfeksiyonun olmadığı ve tam kaynama olduğu görüldü (Şekil 4). ${ }^{[30]}$

\section{Olgu 2}

Seksen iki yaşında erkek hasta sağ dizine uygulanan total diz protezi zemininde aseptik gevşeme nedeniyle tarafımıza başvurdu (Şekil 5). Yapılan revizyon artroplastisi sonrası ara ara dizde şişme ve ağrı şikayetleri olan hasta ameliyat sonrası 1. yılda fistül ağzı ve akıntıyla tarafımıza başvurdu. Radyografide osteomiyelite bağlı osteoliz ve periost reaksiyonu gözlendi (Şekil 6). Hastanın genel durumu, morbidite varlığı, yaşı ve implantının stabil olması nedeniyle klasik iki aşamalı revizyon yerine implantın yerinde bırakılarak debridman ve yıkamalı VAC uygulanmasına karar verildi. Polietilen değiştirildi. Proksimal tibia ve distal femurdaki

osteomiyelit odakları yüksek devirli burr ile debride edildi (Şekil 7). Hastamıza dörder gün arayla üç seans yıkamalı VAC tedavisi uygulandı. Yıkama solüsyonu olarak Prontosan (B Braun) uygulandı. Hastanın CRP düzeyleri normalleşince ve kültür negatifleşince VAC tedavisi sonlandırıldı (Şekil 8). Ameliyat sonrası 2. yılda hastanın CRP değerinin negatif olduğu ve implantta gevşeme bulguları olmadığı görüldü (Şekil 9). 


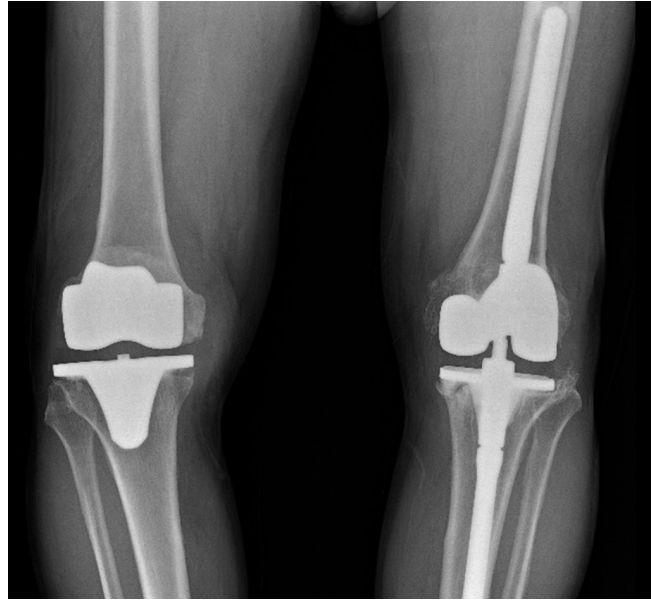

Şekil 5. Seksen iki yaşında erkek hasta; sağ dizde aseptik gevşemede grafi bulguları (Olgu 2).

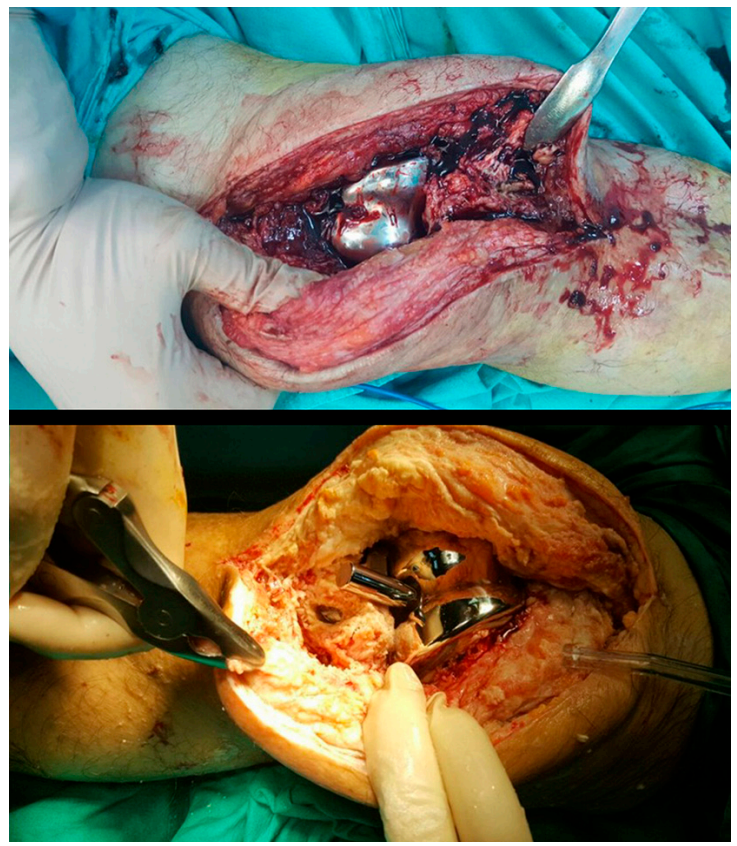

Şekil 7. Proksimal tibia ve distal femurdaki osteomiyelit odaklarına yüksek devirli burr uygulandı (Olgu 2).

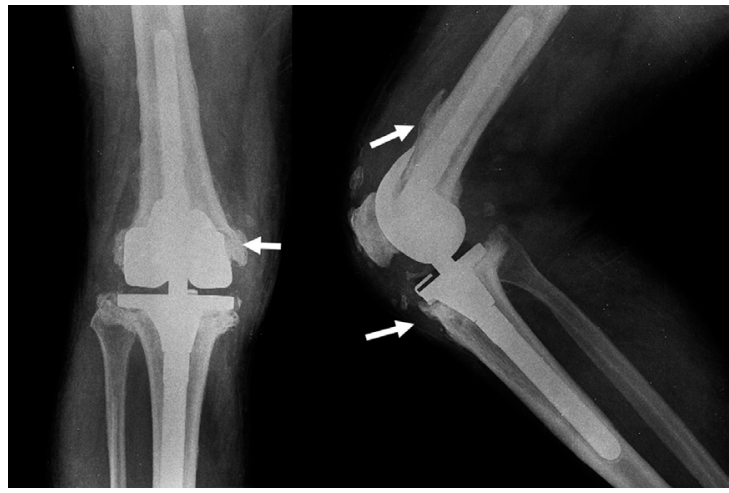

Şekil 9. Hastanın ameliyat sonrası 2. yıl grafisi; hastanın CRP değerleri negatif; implantta gevşeme bulguları yok (Olgu 2).

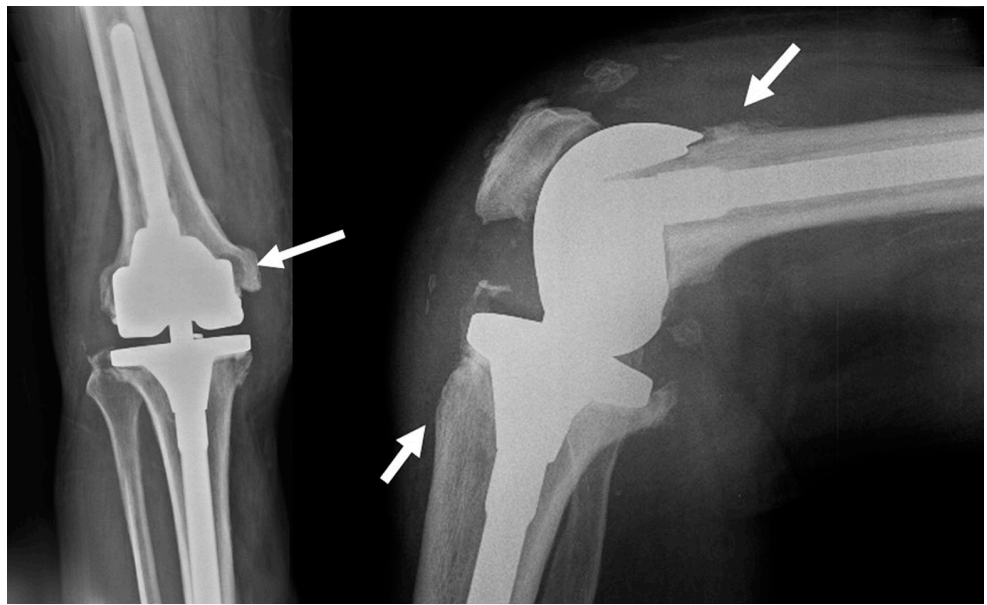

Şekil 6. Radyografide osteomiyelite bağlı osteoliz ve periost reaksiyonu gözlenmektedir (beyaz oklar) (Olgu 2).

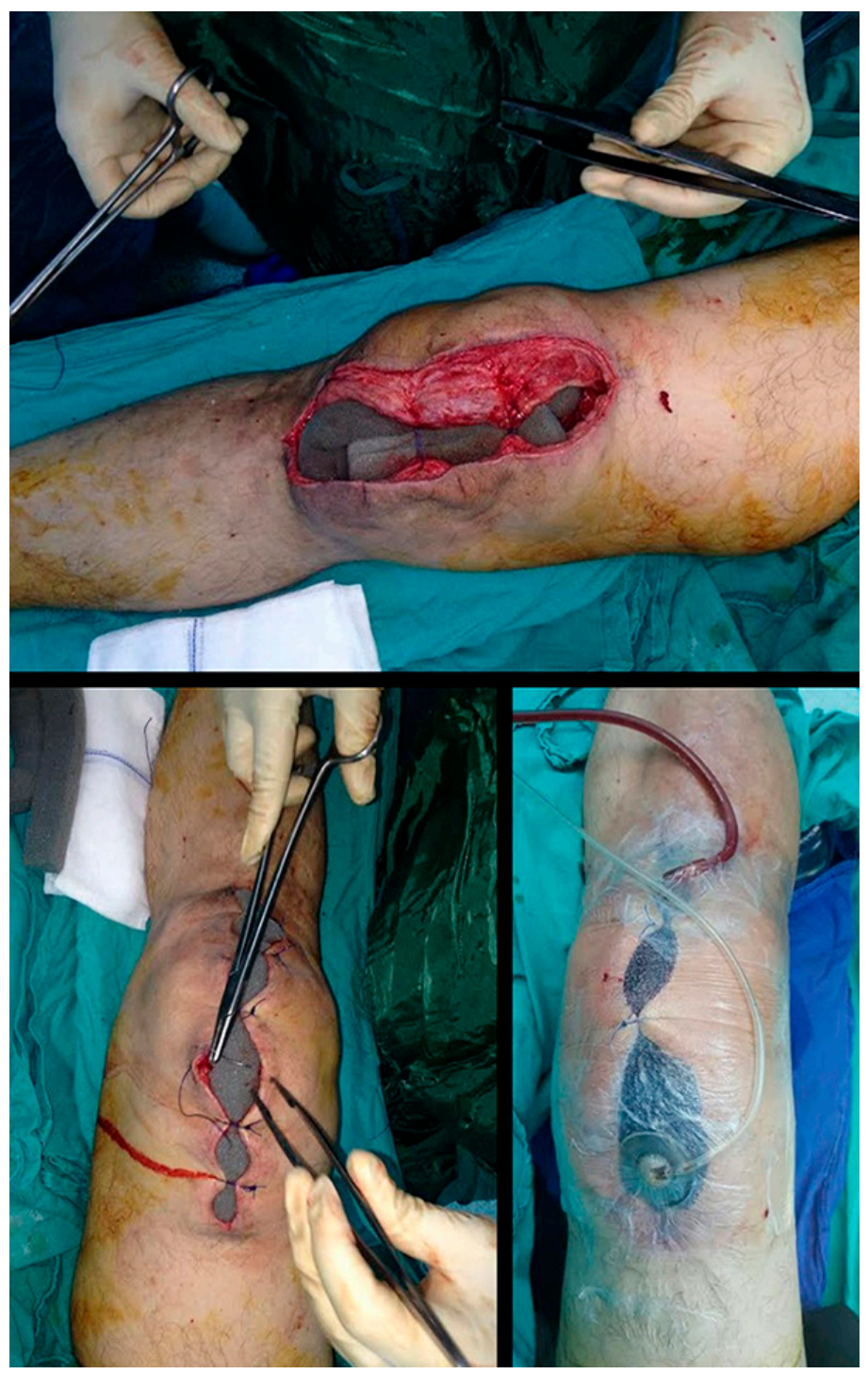

Şekil 8. Hastanın CRP düzeyleri normalleşince ve kültür negatifleşince VAC tedavisi sonlandırıldı (Olgu 2). 


\section{SONUÇ}

VAC tedavisi, implant çevresi enfeksiyonlarda ve osteomiyelitte mucizevi değil ancak etkin çözüm sunan bir yöntem olarak değerlendirilmelidir. Temel tedavi prensiplerine (debridman ve antibiyotik) ek olarak, uygun hastalarda (özellikle erken dönem enfeksiyonlarda ve implant stabilitesinin bozulmadığı kronik enfeksiyonlarda) kullanılması tedavide başarı oranını önemli ölçüde artırabilir. Kronik olgularda (implantlara bağlı enfeksiyonlar) eğer implantta gevşeme bulgusu yoksa yıkamalı VAC tedavisi denenebilir. Bu konuda daha geniş hasta grubuyla yapılacak ileriye dönük çalışmalara ihtiyaç vardır. Enfekte olgularda yıkamalı VAC kullanımı implant çevresi ortopedik enfeksiyonların tedavisinde normal VAC tedavisine göre daha başarılı sonuçlar vermektedir. Tedavide asıl prensibin debridman olduğu unutulmamalıdır. Özellikle kronik osteomiyelit olgularında sekestrumun ortadan kaldırılmadan tedavide başarılı olunması mümkün değildir. Yıkamalı VAC tedavisiyle pratiğimizde $125 \mathrm{mmHg}$ devamlı negatif basınç ve iki saatte bir yaranın hacmine göre ortalama 30-50 cc antiseptik solüsyon tercihan polihekzametilen biguanid + betain kullanarak ve solüsyonu yara içerisinde en az $10 \mathrm{dk}$ bekleterek uygulamayı gerçekleştirmekteyiz. Süngerler beş günde bir değiştirilmekte ve her değişim esnasında yine yaygın olarak debridman uygulanmalıdır. Yara içerisinde görülen granülasyon dokusu enfeksiyonun geçtiğine dair yanıltıcı olabilmektedir. Bundan dolayı granülasyon dokusununda biyofilm açısından sünger değişimi sırasında geniş bir şekilde kürete edilmesi önerilmektedir. Her debridman esnasında kültür alınmalı ve süngerlerden alınan parçalar da mikrobiyolojik incelemeye tabi tutulmalıdırlar. Yine debridman sonrası 4. günde hemogram ve CRP düzeyine bakılmalıdır. Kültür negatif olmadan ve CRP düzeyi normal seviyelere gerilemeden kapatma işlemi uygulanmamalıdır. ${ }^{[26,30]}$

\section{KAYNAKLAR}

1. Bihariesingh V, Stolarczyk EM, Karim RB, van Kooten EO. Plastic solutions for orthopaedic problems. Arch Orthop Trauma Surg 2004;124(2):73-6. Crossref

2. Zimmerli W. Clinical presentation and treatment of orthopaedic implant-associated infection. J Intern Med 2014;276(2):111-9. Crossref

3. Shah MQ, Zardad MS, Khan A, Ahmed S, Awan AS, Mohammad T. Surgical site infection in orthopedic implants and its common bacteria with their sensitivities to antibiotics, in open reduction internal fixation. J Ayub Med Coll Abbottabad 2017;29(1):50-3. http://jamc.ayubmed.edu. pk/index.php/jamc/article/view/900/864

4. Racano A, Pazionis T, Farrokhyar F, Deheshi B, Ghert M. High infection rate outcomes in long bone tumor surgery with endoprosthetic reconstruction in adults: a systematic review. Clin Orthop Relat Res 2013;471(6):2017-27. Crossref
5. Moriarty TF, Kuehl R, Coenye T, Metsemakers WJ, Morgenstern M, Schwarz EM, Riool M, Zaat AJS, Khana $\mathrm{N}$, Kates SL, Richards RG. Orthopaedic device-related infection: current and future interventions for improved prevention and treatment. EFORT Open Rev 2016 1(4):8999. Crossref

6. Fleischmann W, Strecker W, Bombelli M, Kinzl L. Vacuum sealing as treatment of soft tissue damage in open fractures. Unfallchirurg 1993 96(9):488-92. https://pubmed.ncbi.nlm. nih.gov/8235687/

7. Fleischmann W, Lang E, Russ M. Treatment of infection by vacuum sealing. Unfallchirurg 1997;100(4):301-4. Crossref

8. Huang C, Leavitt T, Bayer LR, Orgill DP. Effect of negative pressure wound therapy on wound healing. Curr Probl Surg 2014 51(7):301-31. Crossref

9. Labler L, Keel M, Trentz O, Heinzelmann M. Wound conditioning by vacuum assisted closure (VAC) in postoperative infections after dorsal spine surgery. Eur Spine J 2006;15(9):1388-96. Crossref

10. Canavese F, Krajbich JI. Use of vacuum assisted closure in instrumented spinal deformities for children with postoperative deep infections. Indian J Orthop 2010;44(2):177. Crossref

11. Karaaslan F, Erdem S, Mermerkaya MU. Wound management with vacuum-assisted closure in postoperative infections after surgery for spinal stenosis. Int Med Case Rep J 2015;8:7-11. Crossref

12. Kollrack YBM, Moellenhoff G. Infected internal fixation after ankle fractures -a treatment path. J Foot Ankle Surg 2012;51(1):9-12. Crossref

13. Timmers MS, Graafland N, Bernards TA, Nelissen RGHH, van Dissel JT, Jukema NG. Negative pressure wound treatment with polyvinyl alcohol foam and polyhexanide antiseptic solution instillation in posttraumatic osteomyelitis. Wound Repair Regen 2009;17(2):278-86. Crossref

14. Norris R, Chapman AWP, Krikler S, Krkovic M. A novel technique for the treatment of infected metalwork in orthopaedic patients using skin closure over irrigated negative pressure wound therapy dressings. Ann R Coll Surg Engl 2013;95(2):118-24. Crossref

15. Tan Y, Wang X, Li H, Zheng Q, Li J, Feng G, Pan Z. The clinical efficacy of the vacuum-assisted closure therapy in the management of adult osteomyelitis. Arch Orthop Trauma Surg 2011;131(2):255-9. Crossref

16. Robert N. Negative pressure wound therapy in orthopaedic surgery. Orthop Traumatol Surg Res 2017;103(1):S99-103. Crossref

17. Mouës CM, Vos MC, Van Den Bemd GJCM, Stijnen T, Hovius SER. Bacterial load in relation to vacuum-assisted closure wound therapy: a prospective randomized trial. Wound Repair Regen 2004;12(1):11-7. Crossref

18. Weed T, Ratliff C, Drake DB. Quantifying bacterial bioburden during negative pressure wound therapy: does the wound VAC enhance bacterial clearance? Ann Plast Surg 2004;52(3):2769. Crossref

19. Gabriel A, Shores J, Bernstein B, De Leon J, Kamepalli R, Wolvos T, Baharestani MM, Gupta S. A clinical review of infected wound treatment with vacuum assisted closure ${ }^{\circledR}$ (VAC@) therapy: experience and case series. Int Wound J 2009;6:1-25. Crossref

20. Patmo AS, Krijnen P, Tuinebreijer WE, Breederveld RS. The effect of vacuum-assisted closure on the bacterial load and type of bacteria: a systematic review. Adv Wound Care (New Rochelle) 2014;3(5):383-9. Crossref 
21. Bobkiewicz A, StudniarekA, Drews M, BanasiewiczT. Negative pressure wound therapy with instillation (NPWTi): Current status, recommendations and perspectives in the context of modern wound therapy. NPWTJ 2016;3(1). Crossref

22. Omar M, Gathen M, Liodakis E, Suero EM, Krettek C, Zeckey C, Petri M. A comparative study of negative pressure wound therapy with and without instillation of saline on wound healing. J Wound Care 2016;25(8):475-8. Crossref

23. Goss SG, Schwartz JA, Facchin F, Avdagic E, Gendics C, Lantis JC. Negative pressure wound therapy with instillation (NPWTi) better reduces post-debridement bioburden in chronically infected lower extremity wounds than NPWT alone. J Am Coll Clin Wound Spec 2012;4(4):74-80. Crossref

24. Kelm J, Schmitt E, Anagnostakos K. Vacuum-assisted closure in the treatment of early hip joint infections. Int J Med Sci 2009;6(5):241-6. Crossref

25. Lehner B, Fleischmann W, Becker R, Jukema GN. First experiences with negative pressure wound therapy and instillation in the treatment of infected orthopaedic implants: a clinical observational study. Int Orthop 2011;35(9):141520. Crossref
26. Söylemez MS, Özkan K, Kılıç B, Erinç S. Intermittent negative pressure wound therapy with instillation for the treatment of persistent periprosthetic hip infections: a report of two cases. Ther Clin Risk Manag 2016;12:161. Crossref

27. Miyamura S, Tsuji S, Iwai T, Hamada M. VAC Therapy Direct to the Medullary Cavity for Chronic Tibial Osteomyelitis. Wounds 2016;28(6):E22-6. https://www.woundsresearch. $\mathrm{com} /$ article/vac-therapy-direct-medullary-cavity-chronictibial-osteomyelitis

28. Jukema GN, Timmers MS, Simmen HP, Pape HC. Posttraumatic Osteomyelitis: Improvement in Outcome by Negative Pressure Wound Therapy with Instillation Technique. Praxis (Bern 1994) 2018;107(19):1015-20. Crossref

29. Hirsch T, Seipp HM, Jacobsen F, Goertz O, Steinau HU, Steinstraesser L. Antiseptics in surgery. Eplasty 2010;10:e39. https://www.ncbi.nlm.nih.gov/pmc/articles/PMC2878193/

30. Özkan K, Uygur E, Demiroğlu M, Kılıç B, Erol B. Intermittent negative pressure wound therapy with instillation for the treatment of early chronic infections of two patients with tumor prosthesis. A report of two cases. Presented at EFORT congress as oral presentation, Vienna, AT, 31 May - 2 June 2017. 